\title{
Cost Efficiency of Indian Life Insurance Service Providers using Data Envelopment Analysis
}

\author{
Mihir Dash \\ School of Business, Alliance University \\ India \\ Arpana Muthyala \\ School of Business, Alliance University
}

Received: Nov. 27, 2017 Accepted: March 8, $2018 \quad$ Published: June 1, 2018

doi:10.5296/ajfa.v10i1.12199 URL: https://doi.org/10.5296/ajfa.v10i1.12199

\begin{abstract}
This study examines the cost efficiency of Indian life insurance service providers using Data Envelopment Analysis. The study was performed for a sample of fifteen of the major life insurance companies in India, accounting for $94.77 \%$ of the total market for life insurance in India, over the period of 2010-17. The study extends the scope of cost efficiency by disaggregating the premium collection into components. Also, to provide more detailed insights, the efficiency of the life insurance companies is also analysed with respect to each input and output individually.

The results of the study show that the most efficient Indian life insurance companies are Life Insurance Corporation, which has been consistently 100\% efficient throughout the research period, followed by SBI Life and ICICI Prudential Life, which have also shown consistently high efficiency over the research period. On the other hand, the least efficient life insurance companies are Max New York Life, followed by PNB Met Life, Reliance Life, and Bharati AXA Life. The results of the study also indicate the strengths and weaknesses of the Indian life insurance providers.
\end{abstract}

Keywords: cost efficiency, life insurance service providers, Data Envelopment Analysis. 


\section{Introduction}

Traditionally, India is a country of savers, with household savings either lying idle or invested in non-productive physical assets such as real estate and gold. This is a worrying trend as the savings are getting trapped into non-productive physical assets. In developed countries, insurance is mandatory by law. In developing countries like India, the need for financial security is much greater, as the poor and the middle class constitute a large segment of more than one billion population. The vulnerability to risk of this segment is much greater than the opportunities available to them to recover from a large loss. Life insurance provides financial security against unforeseen circumstances such as death of earning family members.

The Indian insurance industry has been witnessing a period of tremendous growth with the advent of Liberalisation, Privatization, and Globalization policies in the early 1990s. Following the separation of non-life and life businesses of the Insurance market, the number of players has increased drastically. With the increase in the number of players, the growing awareness among the middle-class population, convenience in investing, and the tax benefits, the trend is slowly bending towards insurance and in particular, life insurance.

There are now twenty-four companies operating in India's life insurance market, of which the Life Insurance Corporation (LIC) is the lone public sector company and the other twenty-three companies belong to private sector. In the last few years, the private players have made steady progress in terms of business growth. The prime business operational goal of these players is performance, efficiency, and effectiveness. Efficiency is one of the major concerns for further development of the insurance industry and increased profitability. The list of all registered life insurance companies in India is presented in Table 1 below.

Table 1. Registered life insurance companies in India

\begin{tabular}{|l|l|l|l|}
\hline 1 & Bajaj Allianz Life & 13 & Sahara Life \\
\hline 2 & Exide Life & 14 & Shriram Life \\
\hline 3 & Reliance Life & 15 & Bharti Axa Life \\
\hline 4 & SBI Life & 16 & Future Generali Life \\
\hline 5 & Tata AIA Life & 17 & IDBI Federal Life \\
\hline 6 & HDFC Standard Life & 18 & Canara HSBC OBC Life \\
\hline 7 & ICICI Prudential Life & 19 & Aegon Life \\
\hline 8 & Birla Sun Life & 20 & DHFL Pramerica Life \\
\hline 9 & Aviva Life & 21 & Star Union Dai-Ichi Life \\
\hline 10 & Kotak Mahindra Old Mutual Life & 22 & IndiaFirst Life \\
\hline 11 & Max Life & 23 & Edelweiss Tokio Life \\
\hline 12 & PNB Met Life & 24 & Life Insurance Corporation \\
\hline
\end{tabular}

Over the next ten years, the life insurance market in India is slated to cross US\$ 160 billion making it a huge business opportunity. India currently accounts for only $2 \%$ of the world's life insurance premiums though it is the second most populous nation. It is the fifteenth largest insurance market in the world in terms of premium volume, and has the potential to grow exponentially in the coming years. Life insurance is emerging as one of the big saving 
instruments and the future looks promising for the industry. India's insurable population is expected to touch 750 million in 2020, and life insurance is expected to comprise $35 \%$ of total savings by the end of this decade, as against $26 \%$ in $2009-10$.

The Indian life insurance industry grew at $22.55 \%$ new business premium in $2015-16$, due to the high growth in the group single premium policy, with private insurers growing at $17.63 \%$ and Life Insurance Corporation of India registering a higher growth at $24.74 \%$. The industry is expected to grow at $15 \%$ for the next five years.

\section{Literature Review}

There have been several studies examining the efficiency of life insurance companies. Much of the literature on insurance efficiency is for developed countries, particularly for the US insurance industry (Gardner and Grace, 1993; Yuengert, 1993; Cummins et al, 1999; Greene and Segal, 2004). The following is a review of some of the pertinent efficiency studies in the Indian life insurance context.

The two most common approaches used for efficiency measurement are Data Envelopment Analysis (DEA) and the Stochastic Frontier Approach (SFA). DEA is a nonparametric method that is useful particularly for efficiency measurement for companies in service industries, as it does not require explicit functional form of the production function nor assumptions on the distribution of the inefficiency or random error terms which are required in SFA (Sinha and Chatterjee, 2009). Jarraya and Bouri (2012) provides an extensive survey of different efficiency concepts and measurement methods in the insurance industry. Wise (2017) provides an even more elaborate discussion on the same.

Sinha and Chatterjee (2009) estimated cost efficiency of the life insurance companies operating in India for the period 2002-07 using a modified DEA model approach. They found a trend increase in cost efficiency in 2002-05, which reversed in 2005-07.

Shinde (2012) and Noronh and Shinde (2012) evaluated the cost efficiency of life insurance companies operating in India in the period 2000-10 using DEA. The inputs considered were operational expenditure and commissions paid, while the outputs were benefits paid and net premium. They found Life Insurance Corporation of India to consistently secure a cost efficiency score of $100 \%$, while the cost efficiency score in the case of the private life insurance companies was not very consistent.

Sinha (2015) used a dynamic slacks-based DEA model for measuring the efficiency of life insurance companies in India in the period 2005-12. His results indicated that there was a decline in mean technical efficiency scores for2011-12 as compared to 2008-09, due to the slowdown in the life insurance industry. He also found that the mean technical efficiency of the life insurance companies fluctuated significantly during the research period.

Nandi (2014) examined the efficiency of the top thirteen life insurance companies of India in the period 2002-12 using DEA. The study utilized two inputs, viz. commission paid and operating expenses, and two outputs, viz. premium and net benefit. He estimated the average technical efficiency of the life insurance companies to be $82.6 \%$, pure technical efficiency $87.5 \%$ 
and scale efficiency $94.7 \%$. He also found that Life Insurance Corporation of India was far more efficient than the other life insurance companies.

Bawa and Bhagat (2015) examined the efficiency of life insurance companies registered in Punjab in the period 2006-13 using DEA. They used the number of agents and the number of offices as inputs and net premium and the number of policies as outputs. They found that LIC was $100 \%$ efficient in all the years, and that Aviva Life and SBI Life were $100 \%$ efficient in the first four years of the study period. They estimated the average technical efficiency of life insurance companies in Punjab to be $55.0 \%$, pure technical efficiency $67.9 \%$, and scale efficiency $80.5 \%$.

The review of literature indicates that DEA is the most appropriate technique for efficiency measurement in the life insurance industry. The cost efficiency concept, using commission paid and operating expenses as inputs and net premium and benefits as outputs, is used by most of the studies in the context of the Indian life insurance industry.

\section{Methodology}

The objective of the study is to examine the cost efficiency of life insurance providers in India. To this end, the study uses Data Envelopment Analysis to measure cost efficiency of Indian life insurance service providers. Also, it explores the relationship between efficiency and market power in the Indian life insurance industry.

The analysis was performed for fifteen of the twenty-four registered life insurance service providers, accounting for $94.77 \%$ of the total market for life insurance in India. The list of sample companies is presented in the table 2 below.

Table 2.

\begin{tabular}{|l|l|}
\hline Bajaj Allianz Life & Max New York Life \\
\hline Reliance Life & PNB Met Life \\
\hline SBI Life & Bharti AXA Life \\
\hline HDFC Standard Life & Future Generali Life \\
\hline ICICI Prudential Life & IDBI Federal Life \\
\hline Birla Sun Life & Aegon Life \\
\hline Aviva Life & Edelweiss Tokio Life \\
\hline Life Insurance Corporation & \\
\hline
\end{tabular}

The data for the service providers was obtained from the IRDA (Note 1), Life Insurance Council of India (LICI)(Note 2) and the public disclosures from the insurers' websites (Note 3). The data for the study was taken on a quarterly basis for the period 2010-17.

The efficiency of the life insurance service providers was measured using data envelopment analysis (Farrell, 1957; Charnes et al, 1978; Banker et al, 1984). Data envelopment analysis is a non-parametric technique that identifies the proportion of a DMU's inputs that are effectively required to produce its given levels of outputs, as compared to other DMUs. Mathematically, it is formulated as a linear programming problem follows: 


$$
\min E \text { s.t. } \begin{aligned}
\sum w_{j} & =1 \\
\sum w_{j} I_{i j} & \leq E . I_{i^{*}} \\
\sum w_{j} O_{i j} & \geq O_{i ! !^{*}}
\end{aligned}
$$

In the above formulation, the weights $\mathrm{w}_{\mathrm{j}}$ are associated with the $\mathrm{j}^{\text {th }} \mathrm{DMU} ; \mathrm{I}_{\mathrm{ij}}$ represents the quantity of the $\mathrm{i}^{\text {th }}$ input used by the $\mathrm{j}^{\text {th }} \mathrm{DMU}$; and $\mathrm{O}_{\mathrm{ij}}$ represents the quantity of the $\mathrm{i}^{\text {th }}$ output produced by the $\mathrm{j}^{\mathrm{th}}$ DMU. The target DMU's inputs and outputs are represented by $\mathrm{I}_{\mathrm{i}}{ }^{*}$ and $\mathrm{O}_{\mathrm{i}}{ }^{*}$, respectively, and the efficiency score of the target DMU is represented as E. If the target DMU is not efficient, the formulation above describes a composite of the remaining DMUs that produces at least as much of all the target DMU's outputs using a fraction of its inputs. The efficiency score in this case is the least such fraction. On the other hand, if the target DMU is efficient, in the sense that it is not possible to produce at least as much of all outputs using a fraction of the inputs, its efficiency score is $100 \%$.

In the context of financial service firms, there are three major approaches to measure outputs: the asset or intermediation approach, the user-cost approach, and the value-added approach (Berger and Humphrey, 1992).The asset/intermediation approach views financial service firms purely as financial intermediaries, borrowing funds from customers and transforming the into assets by investing them, and compensating the time value of the funds used through interest payments. However, this approach only considers the intermediation services provided by life insurance firms, ignoring their risk-pooling and risk-bearing functions.

The user-cost approach (Hancock, 1985) classifies financial instruments as an inputs or outputs by analysing if their net contribution to the revenues of the firm is positive or negative. If the returns of an asset exceed the opportunity costs of funds or if the costs of a liability are lower than the opportunity costs, the product is considered as an output; otherwise it is categorised as an input. However, this approach requires detailed information on product revenues and opportunity costs which are difficult to obtain for Indian life insurance firms.

The value-added approach considers all assets and liabilities with substantial value added as the major outputs, and the remaining assets and liabilities are treated either as unimportant outputs, intermediate products, or inputs. This approach is considered most appropriate for measuring output of financial firms and is widely used in insurance studies (Sinha, 2015).

For the present study, the inputs considered include the commissions expenses, operating expenses, and net benefits paid, while the outputs considered include the individual single premium, individual non-single premium, group single premium, and group non-single premium. This is similar to the approach of Shinde (2012), Noronh and Shinde (2012), and Nandi (2014), who used a similar concept of cost efficiency in the context of life insurance firms. By disaggregating premium collections, the efficiency estimates would be expected to be more sensitive. In the research period, individual single premium accounted for $17.26 \%$ of the total premium collection, individual non-single premium accounted for $36.02 \%$, group single premium $37.80 \%$, and group non-single $8.93 \%$. In the last two/three years, years, however, there has been a shift towards group single premium, with about $15 \%$ of total premium collection from individual single premium, about 30\%-33\% from individual 
non-single premium, 46\%-50\% from group single premium, and 5\%-7\% from group non-single premium.

To provide more detailed insights, the efficiency of the sample life insurance companies was also analysed with respect to each input and output individually. Further, to examine the relationship of efficiency with market power (Chuang and Tang, 2015), the resultant efficiency scores were plotted against market shares.

\section{Findings}

The descriptive statistics of the overall efficiency scores for the sample life insurance companies are presented in Table 3 below.

Table 3. Descriptive statistics of overall efficiency scores for the sample life insurance companies

\begin{tabular}{|l|c|c|c|}
\hline & average & std dev & coeff var \\
\hline Aegon Life & $86.71 \%$ & $24.91 \%$ & $28.73 \%$ \\
\hline Aviva Life & $93.92 \%$ & $12.99 \%$ & $13.83 \%$ \\
\hline Bajaj Allianz Life & $93.29 \%$ & $18.33 \%$ & $19.65 \%$ \\
\hline Bharati AXA Life & $79.79 \%$ & $29.78 \%$ & $37.32 \%$ \\
\hline Birla SunLife & $82.04 \%$ & $25.46 \%$ & $31.03 \%$ \\
\hline Edelweiss Tokio Life & $94.74 \%$ & $22.94 \%$ & $24.22 \%$ \\
\hline Future Generali Life & $83.42 \%$ & $27.36 \%$ & $32.80 \%$ \\
\hline HDFC Life & $88.46 \%$ & $19.17 \%$ & $21.67 \%$ \\
\hline ICICI Prudential Life & $96.22 \%$ & $19.23 \%$ & $19.99 \%$ \\
\hline IDBI Federal Life & $92.95 \%$ & $24.81 \%$ & $26.70 \%$ \\
\hline Life Insurance Corporation & $100.00 \%$ & $0.00 \%$ & $0.00 \%$ \\
\hline Max New York Life & $52.22 \%$ & $31.94 \%$ & $61.16 \%$ \\
\hline PNB Met Life & $69.60 \%$ & $28.69 \%$ & $41.21 \%$ \\
\hline Reliance Life & $74.89 \%$ & $23.28 \%$ & $31.09 \%$ \\
\hline SBI Life & $96.65 \%$ & $8.16 \%$ & $8.44 \%$ \\
\hline
\end{tabular}

The efficiency scores indicate that Life Insurance Corporation has been consistently 100\% efficient throughout the research period. SBI Life and ICICI Prudential Life have also shown consistently high efficiency over the research period. The least efficient of the sample life insurance companies was Max New York Life, followed by PNB Met Life and Reliance Life. Bharati AXA Life was also relatively less efficient, and showed high variability in efficiency over the research period.

The descriptive statistics of the efficiency scores with respect to commissions paid (against all of the outputs) for the sample life insurance companies are presented in Table 4 below. 


\section{Macrothink}

Asian Journal of Finance \& Accounting

ISSN 1946-052X

2018, Vol. 10, No. 1

Table 4. descriptive statistics of efficiency scores w.r.t. commissions paid for the sample life insurance companies

\begin{tabular}{|l|c|c|c|}
\hline & average & std dev & coeff var \\
\hline Aegon Life & $76.77 \%$ & $41.85 \%$ & $54.51 \%$ \\
\hline Aviva Life & $82.64 \%$ & $29.47 \%$ & $35.66 \%$ \\
\hline Bajaj Allianz Life & $93.05 \%$ & $21.59 \%$ & $23.20 \%$ \\
\hline Bharati AXA Life & $64.48 \%$ & $40.22 \%$ & $62.37 \%$ \\
\hline Birla Sun Life & $91.37 \%$ & $21.92 \%$ & $23.99 \%$ \\
\hline Edelweiss Tokio Life & $77.67 \%$ & $39.29 \%$ & $50.58 \%$ \\
\hline Future Generali Life & $81.54 \%$ & $31.66 \%$ & $38.83 \%$ \\
\hline HDFC Life & $92.45 \%$ & $26.66 \%$ & $28.83 \%$ \\
\hline ICICI Prudential Life & $95.13 \%$ & $19.96 \%$ & $20.98 \%$ \\
\hline IDBI Federal Life & $79.42 \%$ & $36.15 \%$ & $45.52 \%$ \\
\hline Life Insurance Corporation & $100.00 \%$ & $0.00 \%$ & $0.00 \%$ \\
\hline Max New York Life & $44.39 \%$ & $31.62 \%$ & $71.24 \%$ \\
\hline PNB Met Life & $74.00 \%$ & $26.91 \%$ & $36.37 \%$ \\
\hline Reliance Life & $75.64 \%$ & $24.95 \%$ & $32.98 \%$ \\
\hline SBI Life & $90.07 \%$ & $28.05 \%$ & $31.14 \%$ \\
\hline
\end{tabular}

Life Insurance Corporation was found to be consistently $100 \%$ efficient throughout the research period with respect to commissions paid. ICICI Prudential Life and Bajaj Allianz Life were also found to be consistently highly efficient over the research period. The least efficient of the sample life insurance companies was Max New York Life, followed by Bharati AXA Life, PNB Met Life, and Reliance Life. Aegon Life and Edelweiss Tokio Life were also relatively less efficient, and showed high variability over the research period.

The descriptive statistics of the efficiency scores with respect to operational expenses (against all of the outputs) for the sample life insurance companies are presented in Table 5 below. 


\section{Macrothink}

Asian Journal of Finance \& Accounting

ISSN 1946-052X 2018, Vol. 10, No. 1

Table 5. descriptive statistics of efficiency scores w.r.t. operational expenses for the sample life insurance companies

\begin{tabular}{|l|c|c|c|}
\hline & average & std dev & coeff var \\
\hline Aegon Life & $78.14 \%$ & $23.58 \%$ & $30.18 \%$ \\
\hline Aviva Life & $87.12 \%$ & $18.65 \%$ & $21.41 \%$ \\
\hline Bajaj Allianz Life & $91.53 \%$ & $17.41 \%$ & $19.02 \%$ \\
\hline Bharati AXA Life & $53.44 \%$ & $27.59 \%$ & $51.63 \%$ \\
\hline Birla Sun Life & $95.86 \%$ & $16.36 \%$ & $17.06 \%$ \\
\hline Edelweiss Tokio Life & $100.00 \%$ & $0.00 \%$ & $0.00 \%$ \\
\hline Future Generali Life & $72.02 \%$ & $30.58 \%$ & $42.46 \%$ \\
\hline HDFC Life & $97.30 \%$ & $29.32 \%$ & $30.13 \%$ \\
\hline ICICI Prudential Life & $89.79 \%$ & $16.06 \%$ & $17.89 \%$ \\
\hline IDBI Federal Life & $93.32 \%$ & $20.82 \%$ & $22.31 \%$ \\
\hline Life Insurance Corporation & $100.00 \%$ & $0.00 \%$ & $0.00 \%$ \\
\hline Max New York Life & $55.17 \%$ & $31.56 \%$ & $57.21 \%$ \\
\hline PNB Met Life & $73.62 \%$ & $25.03 \%$ & $34.00 \%$ \\
\hline Reliance Life & $80.19 \%$ & $21.20 \%$ & $26.43 \%$ \\
\hline SBI Life & $99.30 \%$ & $3.66 \%$ & $3.69 \%$ \\
\hline
\end{tabular}

Life Insurance Corporation and Edelweiss Tokio Life were found to be consistently 100\% efficient throughout the research period with respect to operational expenses. SBI Life was also found to be consistently highly efficient over the research period. HDFC Life was also relatively highly efficient, but with higher variability. The least efficient of the sample life insurance companies was Bharati AXA Life, followed by Max New York Life, Future Generali Life, PNB Met Life, and Aegon Life. Bharati AXA Life and Max New York Life also had high variability in efficiency over the research period.

The descriptive statistics of the efficiency scores with respect to individual single premium (against all of the inputs) for the sample life insurance companies are presented in Table 6 below. 


\section{Macrothink}

Asian Journal of Finance \& Accounting

ISSN 1946-052X

2018, Vol. 10, No. 1

Table 6. Descriptive statistics of efficiency scores w.r.t. individual single premium for the sample life insurance companies

\begin{tabular}{|l|c|c|c|}
\hline & average & std dev & coeff var \\
\hline Aegon Life & $72.27 \%$ & $33.86 \%$ & $46.85 \%$ \\
\hline Aviva Life & $42.69 \%$ & $23.68 \%$ & $55.47 \%$ \\
\hline Bajaj Allianz Life & $74.71 \%$ & $28.58 \%$ & $38.25 \%$ \\
\hline Bharati AXA Life & $41.78 \%$ & $25.48 \%$ & $60.98 \%$ \\
\hline Birla Sun Life & $16.70 \%$ & $7.21 \%$ & $43.20 \%$ \\
\hline Edelweiss Tokio Life & $93.98 \%$ & $14.61 \%$ & $15.54 \%$ \\
\hline Future Generali Life & $60.71 \%$ & $31.37 \%$ & $51.66 \%$ \\
\hline HDFC Life & $33.87 \%$ & $23.58 \%$ & $69.62 \%$ \\
\hline ICICI Prudential Life & $24.69 \%$ & $27.44 \%$ & $111.13 \%$ \\
\hline IDBI Federal Life & $90.86 \%$ & $23.32 \%$ & $25.67 \%$ \\
\hline Life Insurance Corporation & $100.00 \%$ & $0.00 \%$ & $0.00 \%$ \\
\hline Max New York Life & $24.98 \%$ & $21.36 \%$ & $85.51 \%$ \\
\hline PNB Met Life & $47.93 \%$ & $32.39 \%$ & $67.57 \%$ \\
\hline Reliance Life & $22.30 \%$ & $12.90 \%$ & $57.86 \%$ \\
\hline SBI Life & $79.79 \%$ & $25.57 \%$ & $32.05 \%$ \\
\hline
\end{tabular}

Life Insurance Corporation was found to be consistently $100 \%$ efficient throughout the research period with respect to individual single premium. Edelweiss Tokio Life and IDBI Federal Life were also found to be consistently highly efficient over the research period. The least efficient of the sample life insurance companies was Birla Sun Life, followed by Reliance Life, ICICI Prudential Life, and Max New York Life, all of which had relatively high variability in efficiency over the research period.

The descriptive statistics of the efficiency scores with respect to individual non-single premium (against all of the inputs) for the sample life insurance companies are presented in Table7 below. 


\section{Macrothink}

Asian Journal of Finance \& Accounting

ISSN 1946-052X 2018, Vol. 10, No. 1

Table 7. descriptive statistics of efficiency scores w.r.t. individual non-single premium for the sample life insurance companies

\begin{tabular}{|l|c|c|c|}
\hline & average & std dev & coeff var \\
\hline Aegon Life & $58.58 \%$ & $43.10 \%$ & $73.58 \%$ \\
\hline Aviva Life & $52.09 \%$ & $35.97 \%$ & $69.05 \%$ \\
\hline Bajaj Allianz Life & $58.42 \%$ & $33.25 \%$ & $56.91 \%$ \\
\hline Bharati AXA Life & $48.32 \%$ & $38.32 \%$ & $79.31 \%$ \\
\hline Birla Sun Life & $51.47 \%$ & $25.60 \%$ & $49.75 \%$ \\
\hline Edelweiss Tokio Life & $57.87 \%$ & $46.18 \%$ & $79.79 \%$ \\
\hline Future Generali Life & $50.61 \%$ & $34.11 \%$ & $67.40 \%$ \\
\hline HDFC Life & $86.76 \%$ & $18.84 \%$ & $21.71 \%$ \\
\hline ICICI Prudential Life & $81.89 \%$ & $25.77 \%$ & $31.47 \%$ \\
\hline IDBI Federal Life & $65.35 \%$ & $43.05 \%$ & $65.88 \%$ \\
\hline Life Insurance Corporation & $100.00 \%$ & $0.00 \%$ & $0.00 \%$ \\
\hline Max New York Life & $29.27 \%$ & $21.74 \%$ & $74.25 \%$ \\
\hline PNB Met Life & $57.93 \%$ & $30.93 \%$ & $53.40 \%$ \\
\hline Reliance Life & $49.91 \%$ & $26.88 \%$ & $53.86 \%$ \\
\hline SBI Life & $93.45 \%$ & $12.09 \%$ & $12.93 \%$ \\
\hline
\end{tabular}

Life Insurance Corporation was found to be consistently $100 \%$ efficient throughout the research period with respect to individual single premium. SBI Life was also found to be consistently highly efficient over the research period, followed by HDFC Life and ICICI Prudential Life. The least efficient of the sample life insurance companies was Max New York Life, followed by Bharati AXA Life and Reliance Life. In fact, most of the sample life insurance companies had relatively low efficiency and relatively high variability in efficiency over the research period.

The descriptive statistics of the efficiency scores with respect to group single premium (against all of the inputs) for the sample life insurance companies are presented in Table 8 below. 


\section{Macrothink}

Asian Journal of Finance \& Accounting

ISSN 1946-052X 2018, Vol. 10, No. 1

Table 8. Descriptive statistics of efficiency scores w.r.t. group single premium for the sample life insurance companies

\begin{tabular}{|l|c|c|c|}
\hline & average & std dev & coeff var \\
\hline Aegon Life & $83.59 \%$ & $25.54 \%$ & $30.55 \%$ \\
\hline Aviva Life & $49.95 \%$ & $23.61 \%$ & $47.28 \%$ \\
\hline Bajaj Allianz Life & $68.99 \%$ & $39.46 \%$ & $57.20 \%$ \\
\hline Bharati AXA Life & $59.29 \%$ & $26.73 \%$ & $45.08 \%$ \\
\hline Birla Sun Life & $15.59 \%$ & $7.67 \%$ & $49.21 \%$ \\
\hline Edelweiss Tokio Life & $91.30 \%$ & $23.39 \%$ & $25.62 \%$ \\
\hline Future Generali Life & $62.32 \%$ & $18.11 \%$ & $29.07 \%$ \\
\hline HDFC Life & $58.34 \%$ & $34.16 \%$ & $58.55 \%$ \\
\hline ICICI Prudential Life & $13.64 \%$ & $15.83 \%$ & $116.08 \%$ \\
\hline IDBI Federal Life & $87.60 \%$ & $22.61 \%$ & $25.82 \%$ \\
\hline Life Insurance Corporation & $100.00 \%$ & $0.00 \%$ & $0.00 \%$ \\
\hline Max New York Life & $7.32 \%$ & $5.14 \%$ & $70.24 \%$ \\
\hline PNB Met Life & $27.27 \%$ & $12.80 \%$ & $46.95 \%$ \\
\hline Reliance Life & $12.91 \%$ & $7.63 \%$ & $59.05 \%$ \\
\hline SBI Life & $78.63 \%$ & $30.85 \%$ & $39.24 \%$ \\
\hline
\end{tabular}

Life Insurance Corporation was found to be consistently $100 \%$ efficient throughout the research period with respect to group single premium. Edelweiss Tokio Life and IDBI Federal Life were also found to be relatively highly efficient over the research period. The least efficient of the sample life insurance companies was Max New York Life, followed by Reliance Life, ICICI Prudential Life, and Birla Sun Life.

The descriptive statistics of the efficiency scores with respect to group non-single premium (against all of the inputs) for the sample life insurance companies are presented in Table 9 below. 


\section{Macrothink}

Asian Journal of Finance \& Accounting

ISSN 1946-052X

2018, Vol. 10, No. 1

Table 9. descriptive statistics of efficiency scores w.r.t. group non-single premium for the sample life insurance companies

\begin{tabular}{|l|c|c|c|}
\hline & average & std dev & coeff var \\
\hline Aegon Life & $75.66 \%$ & $37.32 \%$ & $49.33 \%$ \\
\hline Aviva Life & $56.37 \%$ & $36.50 \%$ & $64.74 \%$ \\
\hline Bajaj Allianz Life & $66.32 \%$ & $34.84 \%$ & $52.53 \%$ \\
\hline Bharati AXA Life & $42.71 \%$ & $27.85 \%$ & $65.20 \%$ \\
\hline Birla Sun Life & $82.94 \%$ & $29.44 \%$ & $35.50 \%$ \\
\hline Edelweiss Tokio Life & $63.79 \%$ & $45.51 \%$ & $71.35 \%$ \\
\hline Future Generali Life & $44.16 \%$ & $37.92 \%$ & $85.88 \%$ \\
\hline HDFC Life & $23.83 \%$ & $26.67 \%$ & $111.88 \%$ \\
\hline ICICI Prudential Life & $29.46 \%$ & $39.27 \%$ & $133.30 \%$ \\
\hline IDBI Federal Life & $75.47 \%$ & $34.78 \%$ & $46.08 \%$ \\
\hline Life Insurance Corporation & $91.11 \%$ & $26.00 \%$ & $28.53 \%$ \\
\hline Max New York Life & $6.12 \%$ & $7.87 \%$ & $128.72 \%$ \\
\hline PNB Met Life & $30.41 \%$ & $23.57 \%$ & $77.53 \%$ \\
\hline Reliance Life & $43.25 \%$ & $35.59 \%$ & $82.27 \%$ \\
\hline SBI Life & $30.55 \%$ & $29.30 \%$ & $95.91 \%$ \\
\hline
\end{tabular}

The efficiency scores with respect to group non-single premium showed relatively high variability for all of the sample insurance companies. Life Insurance Corporation and Birla Sun Life were found to be consistently highly efficient throughout the research period with respect to group non-single premium. The least efficient of the sample life insurance companies was Max New York Life, followed by HDFC Life and ICICI Prudential Life.

The relationship between overall efficiency and market share for the sample private life insurance companies are presented in Table 10 and Figure 1 below. 
Table 10. Overall efficiency vs. market share

\begin{tabular}{|l|c|c|}
\hline & $\begin{array}{c}\text { average } \\
\text { efficiency }\end{array}$ & $\begin{array}{c}\text { market } \\
\text { share }\end{array}$ \\
\hline Aegon Life & $86.71 \%$ & $0.14 \%$ \\
\hline Aviva Life & $93.92 \%$ & $0.48 \%$ \\
\hline Bajaj Allianz Life & $93.29 \%$ & $2.31 \%$ \\
\hline Bharati AXA Life & $79.79 \%$ & $0.32 \%$ \\
\hline Birla Sun Life & $82.04 \%$ & $1.62 \%$ \\
\hline Edelweiss Tokio Life & $94.74 \%$ & $0.08 \%$ \\
\hline Future Generali Life & $83.42 \%$ & $0.24 \%$ \\
\hline HDFC Life & $88.46 \%$ & $3.76 \%$ \\
\hline ICICI Prudential Life & $96.22 \%$ & $4.58 \%$ \\
\hline IDBI Federal Life & $92.95 \%$ & $0.52 \%$ \\
\hline Max New York Life & $52.22 \%$ & $1.91 \%$ \\
\hline PNB Met Life & $69.60 \%$ & $0.71 \%$ \\
\hline Reliance Life & $74.89 \%$ & $1.57 \%$ \\
\hline SBI Life & $96.65 \%$ & $5.13 \%$ \\
\hline
\end{tabular}

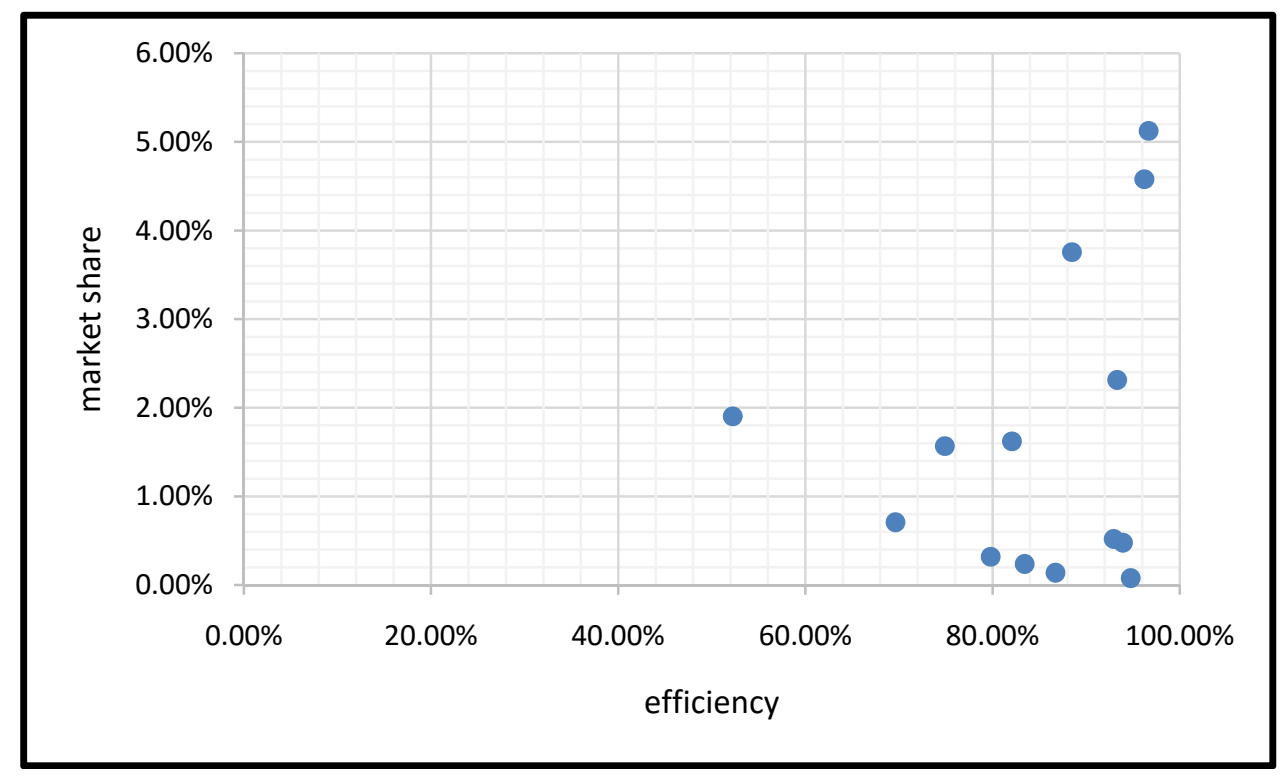

Figure 1. Overall efficiency vs. market share

There was generally a positive relationship between overall efficiency and market share, with some exceptions. However, for each individual insurance company, the relationship between overall efficiency and market share was not statistically significant.

The relationship between efficiency with respect to commissions paid and market share for the sample private life insurance companies are presented in Table 11 and Figure 2 below. 
Table 11. Efficiency w.r.t. commissions paid vs. market share

\begin{tabular}{|l|c|c|}
\hline & $\begin{array}{c}\text { average } \\
\text { efficiency }\end{array}$ & $\begin{array}{c}\text { market } \\
\text { share }\end{array}$ \\
\hline Aegon Life & $76.77 \%$ & $0.14 \%$ \\
\hline Aviva Life & $82.64 \%$ & $0.48 \%$ \\
\hline Bajaj Allianz Life & $93.05 \%$ & $2.31 \%$ \\
\hline Bharati AXA Life & $64.48 \%$ & $0.32 \%$ \\
\hline Birla Sun Life & $91.37 \%$ & $1.62 \%$ \\
\hline Edelweiss Tokio Life & $77.67 \%$ & $0.08 \%$ \\
\hline Future Generali Life & $81.54 \%$ & $0.24 \%$ \\
\hline HDFC Life & $92.45 \%$ & $3.76 \%$ \\
\hline ICICI Prudential Life & $95.13 \%$ & $4.58 \%$ \\
\hline IDBI Federal Life & $79.42 \%$ & $0.52 \%$ \\
\hline Max New York Life & $44.39 \%$ & $1.91 \%$ \\
\hline PNB Met Life & $74.00 \%$ & $0.71 \%$ \\
\hline Reliance Life & $75.64 \%$ & $1.57 \%$ \\
\hline SBI Life & $90.07 \%$ & $5.13 \%$ \\
\hline
\end{tabular}

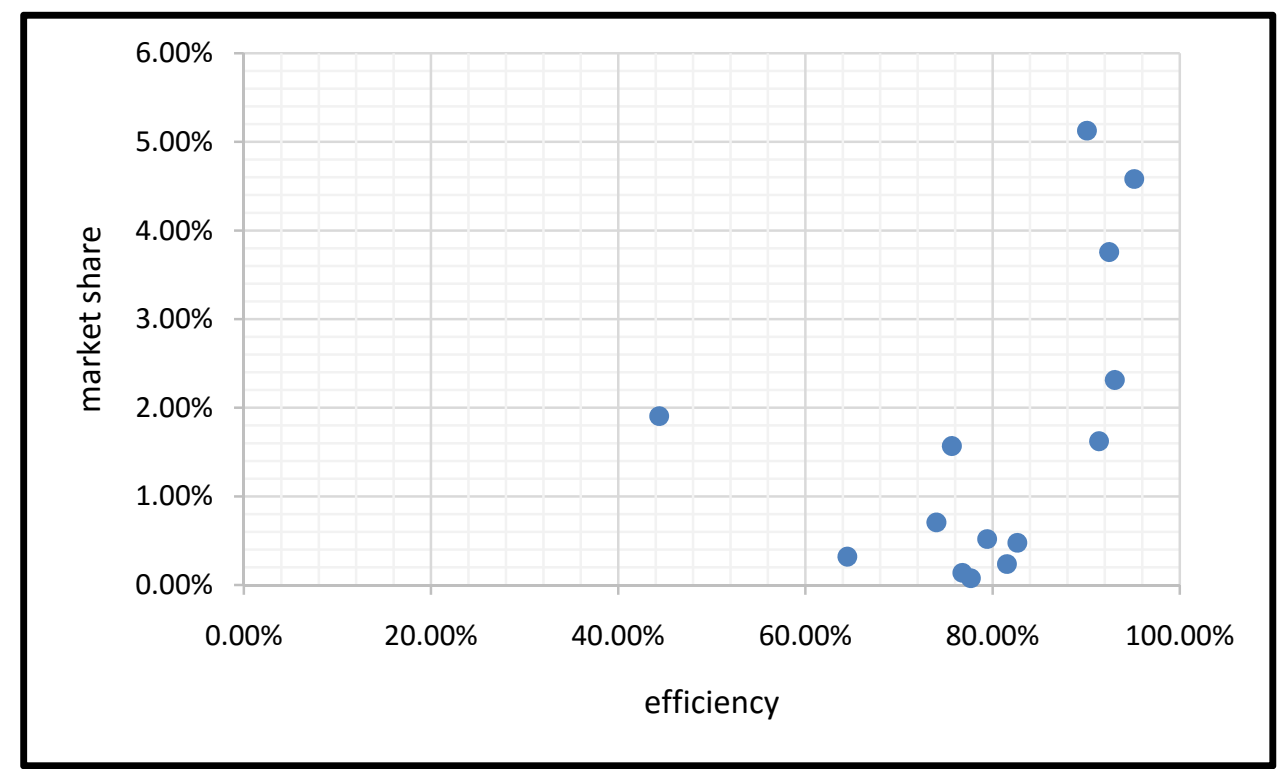

Figure 2. Efficiency w.r.t. commissions paid vs. market share

There was generally a positive relationship between efficiency with respect to commissions paid and market share, with some exceptions.

The relationship between efficiency with respect to operational expenses and market share for the sample private life insurance companies are presented in Table 12 and Figure 3 below. 
Table 12. Efficiency w.r.t. operational expenses vs. market share

\begin{tabular}{|l|c|c|}
\hline & $\begin{array}{c}\text { average } \\
\text { efficiency }\end{array}$ & $\begin{array}{c}\text { market } \\
\text { share }\end{array}$ \\
\hline Aegon Life & $78.14 \%$ & $0.14 \%$ \\
\hline Aviva Life & $87.12 \%$ & $0.48 \%$ \\
\hline Bajaj Allianz Life & $91.53 \%$ & $2.31 \%$ \\
\hline Bharati AXA Life & $53.44 \%$ & $0.32 \%$ \\
\hline Birla Sun Life & $95.86 \%$ & $1.62 \%$ \\
\hline Edelweiss Tokio Life & $100.00 \%$ & $0.08 \%$ \\
\hline Future Generali Life & $72.02 \%$ & $0.24 \%$ \\
\hline HDFC Life & $97.30 \%$ & $3.76 \%$ \\
\hline ICICI Prudential Life & $89.79 \%$ & $4.58 \%$ \\
\hline IDBI Federal Life & $93.32 \%$ & $0.52 \%$ \\
\hline Max New York Life & $55.17 \%$ & $1.91 \%$ \\
\hline PNB Met Life & $73.62 \%$ & $0.71 \%$ \\
\hline Reliance Life & $80.19 \%$ & $1.57 \%$ \\
\hline SBI Life & $99.30 \%$ & $5.13 \%$ \\
\hline
\end{tabular}

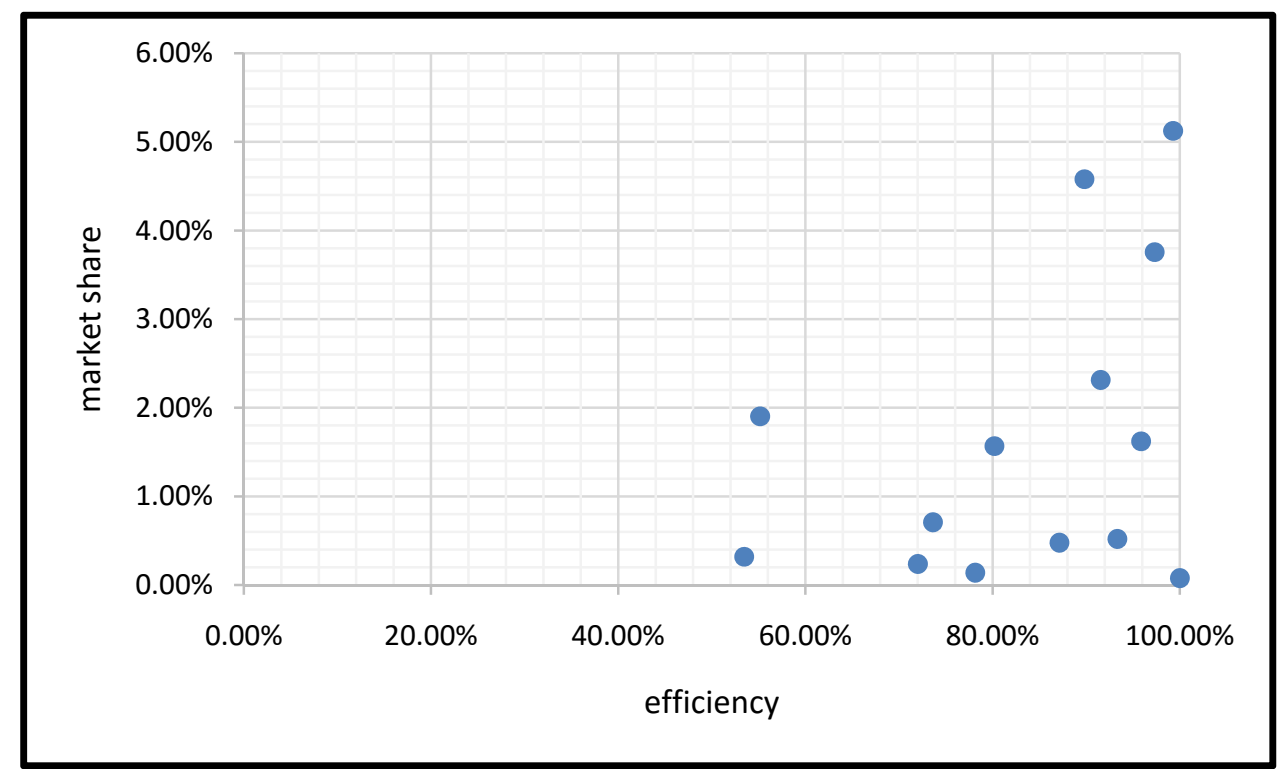

Figure 3. Efficiency w.r.t. operational expenses vs. market share

There was generally a positive relationship between efficiency with respect operational expenses and market share, with some exceptions.

The relationship between efficiency with respect to individual single premium and market share for the sample private life insurance companies are presented in Table 13 and Figure 4 below. 
Table 13. Efficiency w.r.t. individual single premium vs. market share

\begin{tabular}{|l|c|c|}
\hline & $\begin{array}{c}\text { average } \\
\text { efficiency }\end{array}$ & $\begin{array}{c}\text { market } \\
\text { share }\end{array}$ \\
\hline Aegon Life & $72.27 \%$ & $0.14 \%$ \\
\hline Aviva Life & $42.69 \%$ & $0.48 \%$ \\
\hline Bajaj Allianz Life & $74.71 \%$ & $2.31 \%$ \\
\hline Bharati AXA Life & $41.78 \%$ & $0.32 \%$ \\
\hline Birla Sun Life & $16.70 \%$ & $1.62 \%$ \\
\hline Edelweiss Tokio Life & $93.98 \%$ & $0.08 \%$ \\
\hline Future Generali Life & $60.71 \%$ & $0.24 \%$ \\
\hline HDFC Life & $33.87 \%$ & $3.76 \%$ \\
\hline ICICI Prudential Life & $24.69 \%$ & $4.58 \%$ \\
\hline IDBI Federal Life & $90.86 \%$ & $0.52 \%$ \\
\hline Max New York Life & $24.98 \%$ & $1.91 \%$ \\
\hline PNB Met Life & $47.93 \%$ & $0.71 \%$ \\
\hline Reliance Life & $22.30 \%$ & $1.57 \%$ \\
\hline SBI Life & $79.79 \%$ & $5.13 \%$ \\
\hline
\end{tabular}

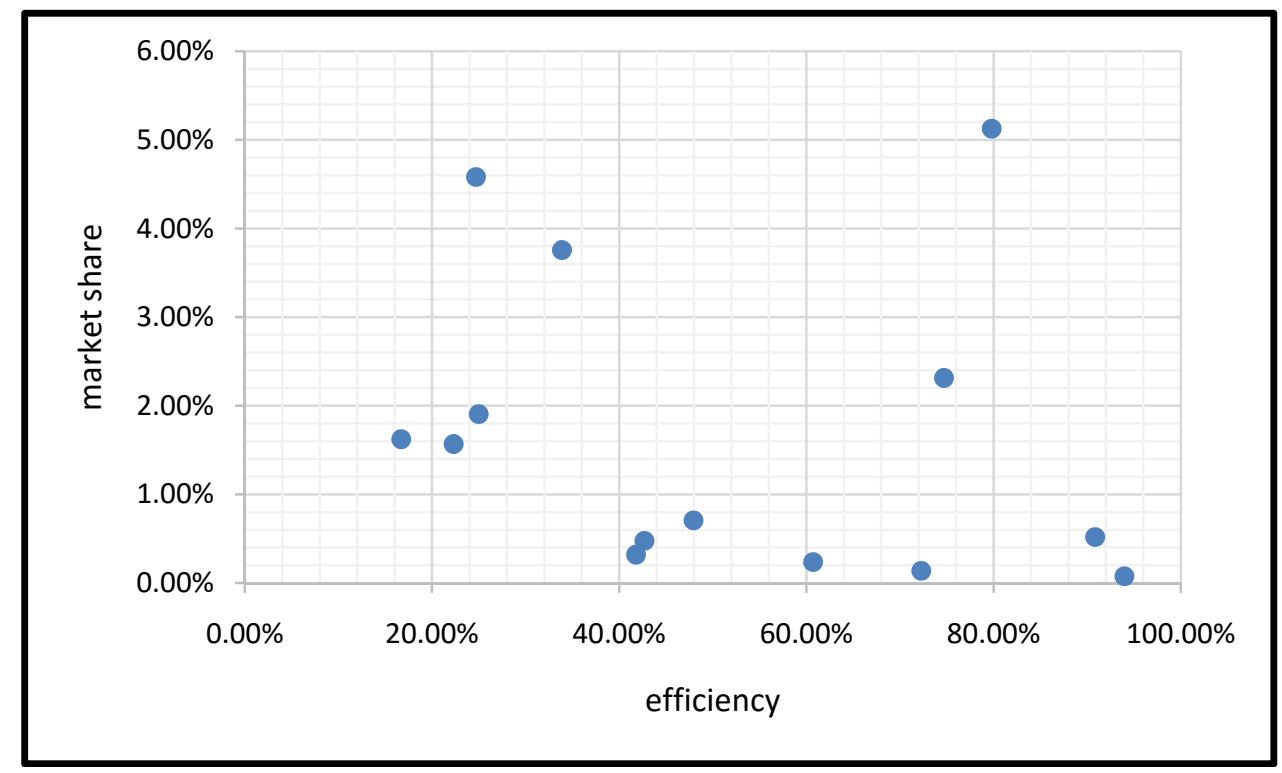

Figure 4. Efficiency w.r.t. individual single premium vs. market share

The relationship between efficiency with respect to individual non-single premium and market share for the sample private life insurance companies are presented in Table 14 and Figure 5 below. 
Table 14. Efficiency w.r.t. individual non-single premium vs. market share

\begin{tabular}{|l|c|c|}
\hline & $\begin{array}{c}\text { average } \\
\text { efficiency }\end{array}$ & $\begin{array}{c}\text { market } \\
\text { share }\end{array}$ \\
\hline Aegon Life & $58.58 \%$ & $0.14 \%$ \\
\hline Aviva Life & $52.09 \%$ & $0.48 \%$ \\
\hline Bajaj Allianz Life & $58.42 \%$ & $2.31 \%$ \\
\hline Bharati AXA Life & $48.32 \%$ & $0.32 \%$ \\
\hline Birla Sun Life & $51.47 \%$ & $1.62 \%$ \\
\hline Edelweiss Tokio Life & $57.87 \%$ & $0.08 \%$ \\
\hline Future Generali Life & $50.61 \%$ & $0.24 \%$ \\
\hline HDFC Life & $86.76 \%$ & $3.76 \%$ \\
\hline ICICI Prudential Life & $81.89 \%$ & $4.58 \%$ \\
\hline IDBI Federal Life & $65.35 \%$ & $0.52 \%$ \\
\hline Max New York Life & $29.27 \%$ & $1.91 \%$ \\
\hline PNB Met Life & $57.93 \%$ & $0.71 \%$ \\
\hline Reliance Life & $49.91 \%$ & $1.57 \%$ \\
\hline SBI Life & $93.45 \%$ & $5.13 \%$ \\
\hline
\end{tabular}

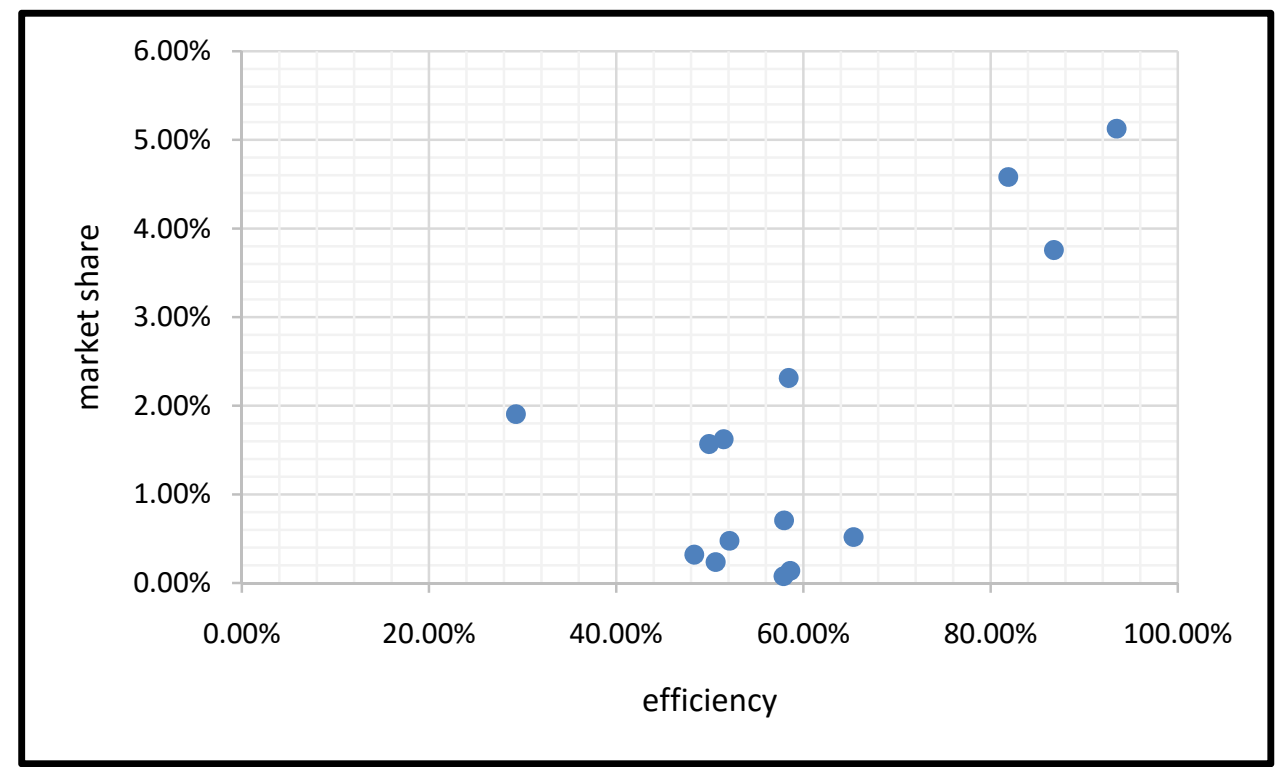

Figure 5. Efficiency w.r.t. individual non-single premium vs. market share

The relationship between efficiency with respect to group single premium and market share for the sample private life insurance companies are presented in Table 15 and Figure 6 below. 
Table 15. Efficiency w.r.t. group single premium vs. market share

\begin{tabular}{|l|c|c|}
\hline & $\begin{array}{c}\text { average } \\
\text { efficiency }\end{array}$ & $\begin{array}{c}\text { market } \\
\text { share }\end{array}$ \\
\hline Aegon Life & $83.59 \%$ & $0.14 \%$ \\
\hline Aviva Life & $49.95 \%$ & $0.48 \%$ \\
\hline Bajaj Allianz Life & $68.99 \%$ & $2.31 \%$ \\
\hline Bharati AXA Life & $59.29 \%$ & $0.32 \%$ \\
\hline Birla Sun Life & $15.59 \%$ & $1.62 \%$ \\
\hline Edelweiss Tokio Life & $91.30 \%$ & $0.08 \%$ \\
\hline Future Generali Life & $62.32 \%$ & $0.24 \%$ \\
\hline HDFC Life & $58.34 \%$ & $3.76 \%$ \\
\hline ICICI Prudential Life & $13.64 \%$ & $4.58 \%$ \\
\hline IDBI Federal Life & $87.60 \%$ & $0.52 \%$ \\
\hline Max New York Life & $7.32 \%$ & $1.91 \%$ \\
\hline PNB Met Life & $27.27 \%$ & $0.71 \%$ \\
\hline Reliance Life & $12.91 \%$ & $1.57 \%$ \\
\hline SBI Life & $78.63 \%$ & $5.13 \%$ \\
\hline
\end{tabular}

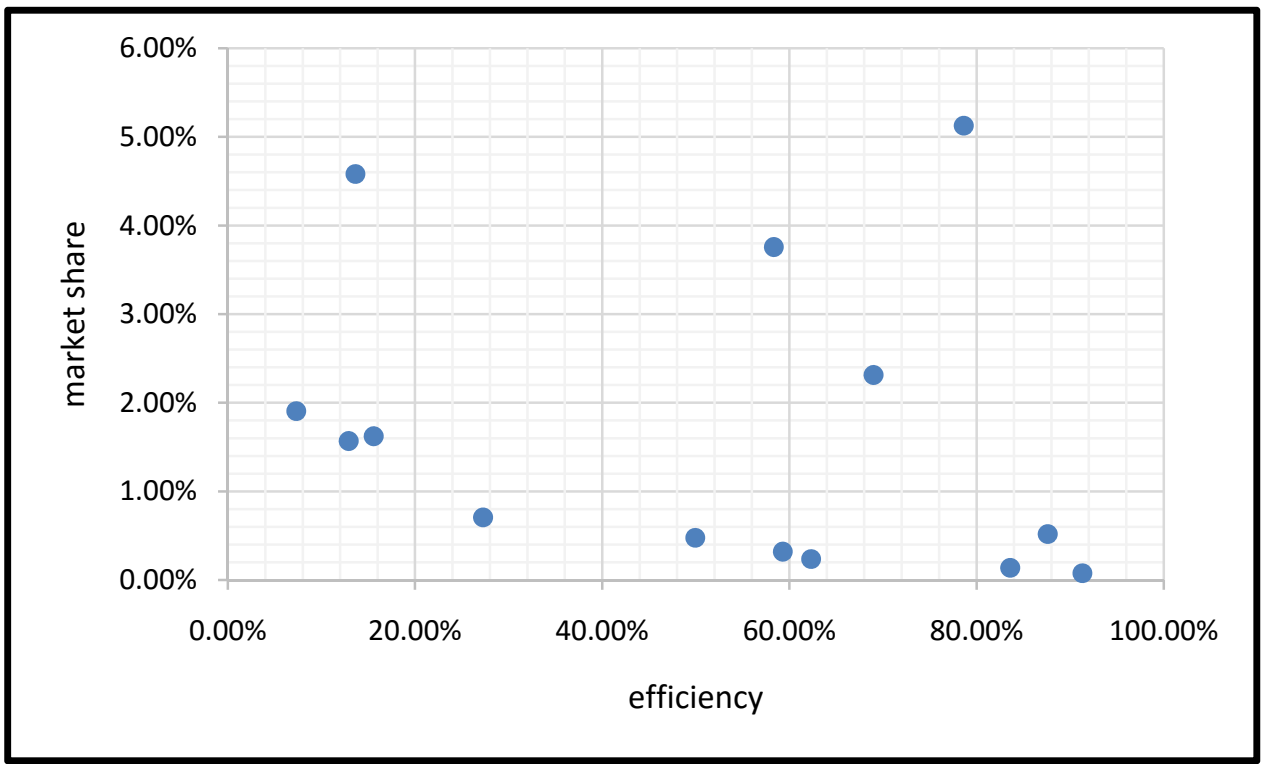

Figure 6. Efficiency w.r.t. group single premium vs. market share

The relationship between efficiency with respect to group non-single premium and market share for the sample private life insurance companies are presented in Table 16 and Figure 7 below. 


\section{Macrothink}

Table 16. efficiency w.r.t. group non-single premium vs. market share

\begin{tabular}{|l|c|c|}
\hline & $\begin{array}{c}\text { average } \\
\text { efficiency }\end{array}$ & $\begin{array}{c}\text { market } \\
\text { share }\end{array}$ \\
\hline Aegon Life & $75.66 \%$ & $0.14 \%$ \\
\hline Aviva Life & $56.37 \%$ & $0.48 \%$ \\
\hline Bajaj Allianz Life & $66.32 \%$ & $2.31 \%$ \\
\hline Bharati AXA Life & $42.71 \%$ & $0.32 \%$ \\
\hline Birla Sun Life & $82.94 \%$ & $1.62 \%$ \\
\hline Edelweiss Tokio Life & $63.79 \%$ & $0.08 \%$ \\
\hline Future Generali Life & $44.16 \%$ & $0.24 \%$ \\
\hline HDFC Life & $23.83 \%$ & $3.76 \%$ \\
\hline ICICI Prudential Life & $29.46 \%$ & $4.58 \%$ \\
\hline IDBI Federal Life & $75.47 \%$ & $0.52 \%$ \\
\hline Max New York Life & $6.12 \%$ & $1.91 \%$ \\
\hline PNB Met Life & $30.41 \%$ & $0.71 \%$ \\
\hline Reliance Life & $43.25 \%$ & $1.57 \%$ \\
\hline SBI Life & $30.55 \%$ & $5.13 \%$ \\
\hline
\end{tabular}

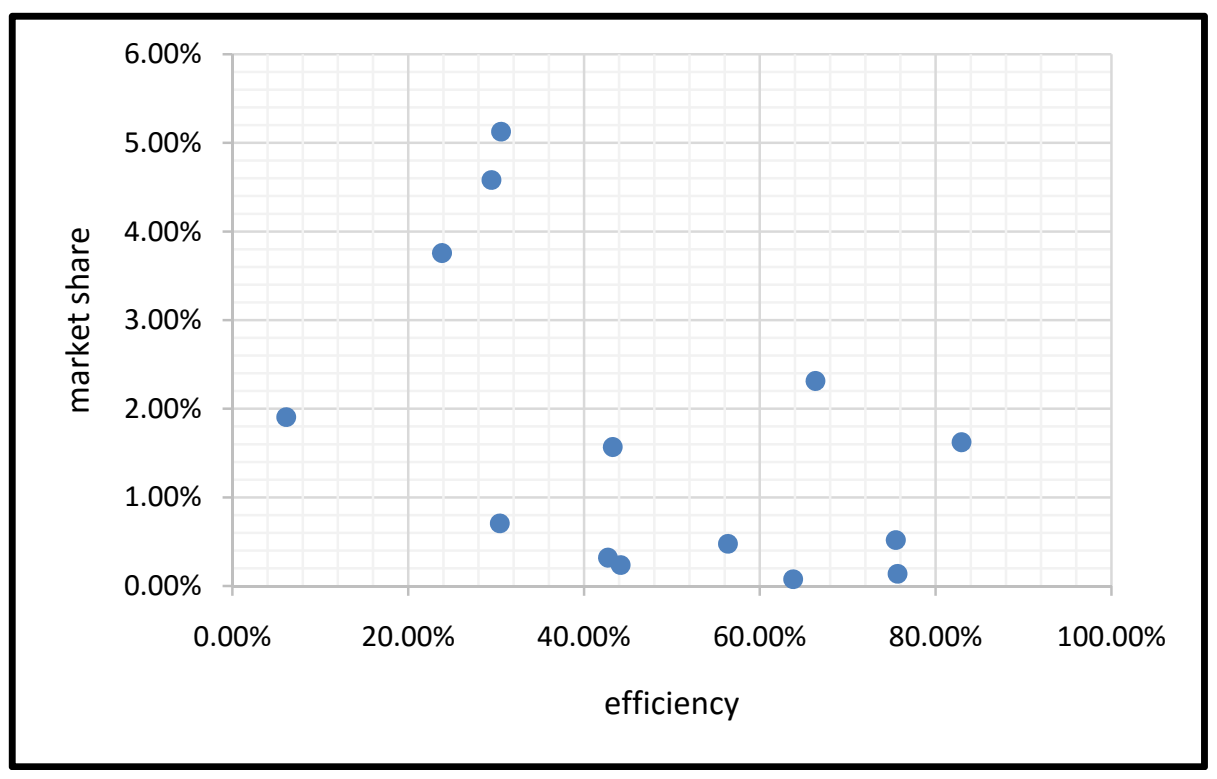

Figure 7. Efficiency w.r.t. group non-single premium vs. market share

There was generally a positive relationship between efficiency with respect individual non-single premium and market share, but the relationship between efficiency with respect to other outputs and market share was mixed.

\section{Discussion}

The results of the study show that the most efficient Indian life insurance companies are Life Insurance Corporation, which has been consistently 100\% efficient throughout the research period, followed by SBI Life and ICICI Prudential Life, which have also shown consistently 
high efficiency over the research period. On the other hand, the least efficient life insurance companies are Max New York Life, followed by PNB Met Life, and Reliance Life. Bharati AXA Life is also relatively less efficient, with high variability in efficiency over the research period. The results of the analysis of efficiency with respect to individual inputs and outputs were similar, with Life Insurance Corporation almost always 100\% efficient throughout the research period, along with SBI Life and ICICI Prudential Life at the higher end, and Max New York Life, PNB Met Life, Reliance Life, and Bharati AXA Life at the lower end.

The results of the study emphasise that Life Insurance Corporation is the dominant player in the Indian life insurance industry. This conforms with the results of most previous studies (Shinde, 2012, Noronh and Shinde, 2012; Nandi, 2014; Bawa and Bhagat, 2015). Life Insurance Corporation was found to be $100 \%$ efficient in all the analyses except for efficiency with respect to group non-single premium. This could be an effect of the decline in this sub-segment of the life insurance industry in recent years.

The results suggest very high variability in efficiency of most of the sample life insurance companies. This conforms with the results of Sinha and Chatterjee (2009) and Sinha (2015). It is a possibility that life insurance business is affected by seasonality. The two expected peak seasons are Q2 and Q4. The former, Q2, is expected to be a peak as it is the festival season in India, and almost all sectors have a spurt in sales in this quarter. The latter, Q4, is the close of the financial year, and many individuals and firms tend to buy insurance in this quarter, for example, to manage their investments and tax deductions. The data for the current study was taken for this reason. Unfortunately, apart from some evidence in seasonality in the market share of Life Insurance Corporation in the early part of the research period (with a low in Q3), no seasonality in the efficiency scores was identifiable.

There are some limitations inherent in the study. The data for the study was censored to some extent; in some years, some data was unavailable. For example, cost data for Future Generali Life was not available for the year 2015-16 and Q3 of 2016-17. Also, Edelweiss Tokio Life entered the industry in 2011-12, and its cost data was available only from Q1 of 2012-13. The efficiency scores may thus be somewhat biased.

A limitation of DEA is that the results are generally sensitive to the choice of inputs and outputs (Gutierrez-Nieto et al., 2007). Although the study has extended the concept of cost efficiency by disaggregating the outputs, the results are not really very different from those of earlier studies. Some in efficiencies that have been identified need to be analysed further, particularly for the weak players, viz. Max New York Life, PNB Met Life, Reliance Life, and Bharati AXA Life, in order to understand how they can improve their efficiency.

There is a scope to include more variables in the analysis to refine the efficiency score. Also, the study may be extended by analysing the critical factors predicting inefficiency. This would be of interest to regulators to help identify inefficient players.

Another limitation of DEA is that it may overestimate the efficiency of the smallest and largest DMUs. This could have distorted the efficiency estimates for the smaller players, for example, for Edelweiss Tokio Life, even if the outputs are negligible. 


\section{References}

Bawa, S.K., \& Bhagat, N. (2015). Efficiency of Life Insurance Companies Operating in Punjab. Pacific Business Review International, 7(9), 76-85.

Charnes, A., Cooper, W.W., \& Rhodes, E. (1978). Measuring the efficiency of DMUs. European Journal of Operational Research 2, 429-444. https://doi.org/10.1016/0377-2217(78)90138-8

Chuang, C.-C., \& Tang, Y.-C. (2015). Asymmetric Dependence between Efficiency and Market Power in the Taiwanese Life Insurance Industry. Panoeconomicus, 62(4), 511-525. https://doi.org/10.2298/PAN1504511C

Cummins, D., Tennyson, S., \& Weiss M. (1999). Consolidation and efficiency in the US life insurance industry. Journal of Banking and Finance, 23, 325-357. https://doi.org/10.1016/S0378-4266(98)00089-2

Farrell, M.J. (1957). The Measurement of Productive Efficiency. Journal of the Royal Statistical Society, 120, 253-281. https://doi.org/10.2307/2343100

Gardner, L., \& Grace, M. (1993). X-efficiency in the US life insurance industry. Journal of Banking and Finance, 17, 497-410. https://doi.org/10.1016/0378-4266(93)90048-I

Greene, W., \& Segal, D. (2004). Profitability and efficiency in the U.S. life insurance industry. Journal of Productivity Analysis, 229-247. https://doi.org/10.1023/B:PROD.0000022092.70204.fa

Gutierrez-Nieto, B., Serrano Cinca C., \& Mar Molinero C. (2009). Social Efficiency in Microfinance Institutions. Journal of the Operational Research Society, 60(19), 104-119. https://doi.org/10.1057/palgrave.jors.2602527

Jarraya, B., \& Bouri, A. (2012). Efficiency concept and investigations ininsurance industry: A survey. Munich Personal RePEc Archive, Paper No. 53544.

Nandi, J.K. (2014). Relative Efficiency Analysis of Selected Life Insurers in Indiausing Data Envelopment Analysis. Pacific Business Review International, 6(8), 69-76.

Noronh, M.R., \& Shinde, S.R. (2012). A Comparative Study ofCost Efficiency of Life InsuranceCompanies in India. Ganpat University Faculty of Management Studies Journal of Management and Research, 4, 1-14.

Shinde, S.R. (2012). A comparative study of cost efficiency of life insurance companiesin India. International Journal of Commerce and Business Management, 5(2), 210-215.

Sinha, R.P. (2015). A Dynamic DEA Model for IndianLife Insurance Companies. Global Business Review, 16(2), 258-269.

Sinha, R.P., \& Chatterjee, B. (2009). Are Indian Life Insurance Companies Cost Efficient? Paper presented at the 11th Annual Conference on Money and Finance, Indira Gandhi 


\section{Macrothink}

Asian Journal of Finance \& Accounting ISSN 1946-052X 2018, Vol. 10, No. 1

Institute of Development Research, Mumbai, India held January 23-24, 2009. https://doi.org/10.1177/0972150914564418

Wise, W. (2017). A survey of life insurance efficiency papers: methods, pros and cons, trends. Accounting, 3, 137-170. https://doi.org/10.5267/j.ac.2016.12.001

Yuengert, M.A. (1993). The measurement of efficiency in life insurance: Estimates of mixed normal-gamma error model. Journal of Banking and Finance, 17, 483-496. https://doi.org/10.1016/0378-4266(93)90047-H

\section{Notes}

Note 1. https://www.irdai.gov.in/

Note 2. http://www.lifeinscouncil.org/

Note

https://www.lifeinscouncil.org/industry\%20information/Public_Disclosures.aspx 